\title{
Description of the uEMEP_v5 downscaling approach for the EMEP MSC-W chemistry transport model
}

\section{Supplementary material}

5 Bruce Rolstad Denby ${ }^{1}$, Michael Gauss ${ }^{1}$, Peter Wind ${ }^{1,2}$, Qing Mu${ }^{1}$, Eivind Grøtting Wærsted ${ }^{1}$, Hilde Fagerli $^{1}$, Alvaro Valdebenito ${ }^{1}$, Heiko Klein ${ }^{1}$

${ }^{1}$ The Norwegian Meteorological Institute, Henrik Mohns Plass 1, 0313, Oslo, Norway

${ }^{2}$ Department of Chemistry, UiT - The Arctic University of Norway, N-9037 Tromsø, Norway

Correspondence to: Bruce Rolstad Denby (brucerd@met.no)

10 The following supplementary material provides additional detailed equations, parameter descriptions and sensitivity study results to the main article of the same name. It is structured with the same section headers as given in the main article, prefixed with ' $\mathrm{S}$ '.

\section{S3 UEMEP model process description and parameterisation}

\section{S3.1 $\mathrm{K}_{\mathrm{z}}$ profiles used in EMEP and uEMEP}

15 For unstable conditions $(\mathrm{L}<0)$ the $\mathrm{K}_{\mathrm{z}}$ vertical diffusion profiles are given by the formulation from O’Brien (1970)

$$
\begin{aligned}
& K_{z}(z)=\frac{\kappa u_{*} z}{\phi_{h}} \text { for } z<h_{s} \\
& K_{z}(z)=K_{z}(H)+\left(\frac{H-z}{H-h_{s}}\right)^{2}\left(K_{z}\left(h_{s}\right)-K_{z}(H)+\left(z-h_{s}\right)\left(\frac{\delta K_{z}\left(h_{s}\right)}{d \delta z}+2\left(\frac{K_{z}\left(h_{s}\right)+K_{z}(H)}{H-h_{s}}\right)\right) \text { for } h_{s} \leq z<H\right. \\
& K_{z}(z)=K_{z}(H) \text { for } z>H
\end{aligned}
$$

20

The height of the surface layer is set to $h_{s}=0.04 H$ (Pielke, 2002) and the dispersion at the top of the boundary layer is set to a minimum of $K_{z}(H)=0.001 \mathrm{~m}^{2} \mathrm{~s}^{-1}$.

For stable conditions the formulation from Jeričevič et al. (2010) is applied, as in the EMEP MSC-W model

$$
K_{Z}(z)=\frac{a_{K} u_{*} Z}{\phi_{h}} \exp \left(-0.5\left(\frac{z}{b_{K} H}\right)^{2}\right)
$$


where $a_{K}=0.39$ and $b_{K}=0.32\left(b_{K}=0.21\right.$ in the original version $)$

30 These two formulations do not match under neutral conditions, so the parameter $b_{K}$ in Eq. (S2) has been slightly changed to those reported in Simpson et al. (2012). In addition, in Simpson et al. (2012) only the neutral case was used. In uEMEP, stability is included with a minimum positive Monim-Obuhkov length $L=25 \mathrm{~m}$ and a maximum negative $L=-10 \mathrm{~m}$.

\section{S3.2 Stability functions}

The stability functions $\psi_{m}$ and $\phi_{m}$ are defined, as in Garratt (1994), as

35

$$
\begin{aligned}
& \phi_{m, h}=1+b \frac{z}{L} \text { for } L \geq 0 \\
& \phi_{m}=\left(1-a \frac{z}{L}\right)^{p} \text { for } L<0 \\
& \phi_{h}=\left(1-a \frac{z}{L}\right)^{q} \text { for } L<0
\end{aligned}
$$

40 and the integrated forms are given by

$$
\begin{aligned}
& \psi_{m, h}=-b \frac{z}{L} \text { for } L \geq 0 \\
& \psi_{m}=2 \log \left(\frac{1}{2}\left(1+\frac{1}{\phi_{m}}\right)\right)+2 \log \left(\frac{1}{2}\left(1+\frac{1}{\phi_{m}^{2}}\right)\right)+2 \tan ^{-1}\left(\frac{1}{\phi_{m}}\right)+\frac{\pi}{2} \text { for } L<0 \\
& \psi_{h}=2 \log \left(\frac{1}{2}\left(1+\frac{1}{\phi_{h}}\right)\right) \text { for } L<0
\end{aligned}
$$

45

The constants are given as $a=16, b=5, p=-0.25$ and $q=-0.5$.

\section{S3.3 Assumptions in the derivation of the vertical wind profile}

The wind profile given in Sect. 3.3, Eq. (22), has been derived using the assumption that

$$
\frac{d U(z)}{d z}=\frac{u_{*}(z)}{\lambda(z)}
$$

Where the length scale is given as

$$
\frac{1}{\lambda}=\frac{\phi_{m}}{\kappa z}+\frac{1}{z_{l}}
$$


with the asymptotic limiting length scale $z_{l}=0.4 H$, where $H$ is the height of the boundary layer. In Gryning et al. (2007) this asymptotic limit was defined using Rossby similarity theory but we have simplified here. The turbulent velocity scale $u *$ in the boundary layer is described as a linear function of height, as in Gryning et al. (2007)

60

$$
\begin{aligned}
& u_{*}(z)=u_{* 0}\left(1-\frac{z}{H}\right) \text { for } z \leq H \\
& u_{*}(z)=0 \text { for } z>H
\end{aligned}
$$

\section{S3.4 Other additional and optional parameterisations}

In this section a number of additional parameterizations employed in the model are presented

\section{S3.4.1 Meandering and change of wind direction}

Meandering at low wind speeds has been shown to have a significant effect on the horizontal dispersion (Etling, 1990; Hiscox et al., 2010). We have implemented a simple meandering scheme that increases the horizontal dispersion dependent on wind speed in the following way:

$$
\sigma_{y, \text { meander }}=x \frac{2 \pi}{360} \theta_{\text {meander }} \exp \left(-\frac{U-U_{\min }}{2 U_{\min }}\right)
$$

where $x$ is the along plume distance, $\theta_{\text {meander }}$ is the maximum meandering angle $\left(20^{\circ}\right), U$ is the wind speed in the dispersion and $U_{\min }$ is the minimum allowable wind speed for the dispersion calculations, $0.5 \mathrm{~m} / \mathrm{s}$. This means, for example, that for a wind speed of $2 \mathrm{~m} / \mathrm{s}$ the meandering angle will be $4^{\circ}$.

75

Similarly, a change of wind direction from one hour to the next in the model domain will also lead to an increase in the effective horizontal dispersion. This is simply written as

$$
\sigma_{y, \Delta \text { wind }}=x \frac{2 \pi}{360} \Delta \theta_{\text {wind }}
$$

80

where $\Delta \theta_{\text {wind }}$ is the difference in wind direction, in degrees, at the emission grid from one model hour to the next. These values are then added to the horizontal dispersion calculated with Eq. (15b). 


\section{S3.4.2 Trajectories and downwind selection of the moving window}

All meteorological data read by uEMEP are interpolated, using bilinear interpolation, to the sub-grid level onto a 85 meteorological sub-grid for use in the dispersion calculations. For sub-grid calculations of $50-100 \mathrm{~m}$ then the interpolation is usually done to $250 \mathrm{~m}$. This provides smoother wind fields for the trajectory calculations.

The dispersion formulation may follow horizontal trajectories in the model domain for any given hourly meteorological field. These trajectories are calculated for each emission grid and the dispersion calculation is carried out along these trajectories.

90 This can become complex if the trajectories change angle significantly but this rarely occurs in the modelled meteorology. Trajectories are calculated at intervals smaller than the meteorological grid spacing; this is specified by the user but trajectory spacing is somewhere between the sub-grid and the grid resolution.

In addition to the trajectories uEMEP also determines the upwind sector for any receptor sub-grid and adjusts the position of

95 the moving window to only include the upwind region. This is principally intended to save computational time, so that the model does not search for emissions in downwind regions.

\section{S3.4.3 Traffic induced initial dispersion}

To reflect the impact of traffic speed on the initial dispersion due to traffic turbulence then a simple parameterization is used that increases the initial vertical and horizontal dispersion as a function of traffic speed. This is described using a limited linear

100 function with minimum and maximum allowable $\sigma_{z, \text { traffic }}$ of 0.5 and $3.0 \mathrm{~m}$, respectively.

$$
\begin{aligned}
& \sigma_{\text {init,z,traffic }}=0.5 \text { for speed }<40 \mathrm{~km} / \mathrm{h} \\
& \sigma_{\text {init,z,traffic }}=0.5+\frac{(3.0-0.5)}{(100-40)}(\text { speed }-40) \text { for } 40 \mathrm{~km} / \mathrm{h}<\text { speed }<100 \mathrm{~km} / \mathrm{h} \\
& \sigma_{\text {init }, \text { traffic }}=3.0 \text { for speed }>100 \mathrm{~km} / \mathrm{h}
\end{aligned}
$$

105

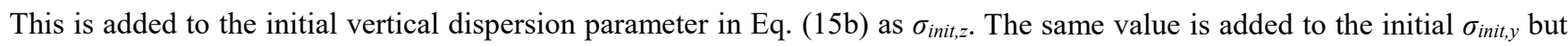
with the addition of road width in the following way

$$
\sigma_{\text {init }, y, \text { traffic }}=\sqrt{\sigma_{\text {init }, z, \text { traffic }}^{2}+(0.5 \text { roadwidth })^{2}}
$$

\section{S3.4.4 Temperature dependence of NOx traffic emissions}

Recently the temperature dependence of $\mathrm{NO}_{\mathrm{X}}$ traffic exhaust emissions has been shown to be significant (Keller et al., 2017; Weber et al., 2019; Hagman et al., 2011; Grange et al., 2019). In Norway the majority of $\mathrm{NO}_{\mathrm{x}}$ emissions are from diesel 
vehicles so an additional temperature dependence has been included in the forecast application, since this is not currently in the national emission inventory. The following scaling factor $\left(S_{N O x}\right)$ is used:

115

$$
\begin{aligned}
& s_{N O x}=1 \text { for } T_{\text {air }}>+5{ }^{\circ} \mathrm{C} \\
& s_{\text {NOx }}=1-\frac{2\left(T_{\text {air }}-5\right)}{15} \text { for }-10{ }^{\circ} \mathrm{C}<T_{\text {air }}<+5{ }^{\circ} \mathrm{C} \\
& s_{\text {NOx }}=3 \text { for } T_{\text {air }}<-10{ }^{\circ} \mathrm{C}
\end{aligned}
$$

120 This differs from the curve presented in HBEFA (Keller et al., 2017), which does not include any increase in emission factors below $0{ }^{\circ} \mathrm{C}$. Eq. (S13) reflects more recent measurements (Weber et al., 2019). We consider this a preliminary estimate as the temperature dependence still requires further study.

\section{S3.4.5 Tunnel emissions and deposition}

Most emissions within a tunnel will exit at the tunnel portals, but a fraction will remain in the tunnels through deposition. This

125 effect is most important for particles in long tunnels. Ventilation towers are not currently included in the model. Tunnels are also assumed to always be dry, so road dust is continuously emitted within them even when it is wet outside. A tunnel deposition model is applied that determines the reduction of the emissions at tunnel portals, the tunnel emission scaling factor $\left(f_{\text {tunnel }}\right)$. This is based on the specified deposition velocities of the pollutant, $w_{\text {dep }}(\mathrm{cm} / \mathrm{s})$, the wind speed in the tunnel $U_{\text {tunnel }}$ $(\mathrm{m} / \mathrm{s})$, the length of the tunnel, $L_{\text {tunnel }}(\mathrm{m})$, and the effective radius of the tunnel $R_{\text {tunnel }}(\mathrm{m})$. Deposition is assumed to occur on

130 all walls of the tunnel. For low deposition rates, high wind speeds and large tunnel radii then the reduction of pollutant emissions is least. For a typical long tunnel of $5 \mathrm{~km}$ then a reduction of tunnel portal emissions of $30 \%$ can be expected for $\mathrm{PM}_{10}$.

$$
f_{\text {tunnel }}=\frac{1-\exp \left(-\beta . L_{\text {tunnel }}\right)}{\beta . L_{\text {tunnel }}}
$$

$$
\beta=\frac{2 w_{\text {dep }}}{100 U_{\text {tunnel }} R_{\text {tunnel }}}
$$

Deposition velocities used in the model are $0.1 \mathrm{~cm} / \mathrm{s}\left(\mathrm{PM}_{10}\right), 0.05 \mathrm{~cm} / \mathrm{s}\left(\mathrm{PM}_{2.5}\right)$ and $0.02 \mathrm{~cm} / \mathrm{s}\left(\mathrm{NO}_{2}\right)$.

\section{S4.2 Emissions}

The EMEP calculations make use of the CAMS-REG-AP_v1.1 emission dataset everywhere in Europe (Kuenen et al., 2014;

140 Granier et al., 2019). Only in the $2.5 \mathrm{~km}$ Scandinavian calculation, and only in Norway, are the emissions replaced with the aggregated high resolution dataset. The alternative emissions used in the calculations for Norway, and described in the following sections, are: 
- Road traffic exhaust emissions

- Road traffic non-exhaust emissions

- Residential wood combustion

- Shipping

- Industry

\section{S4.2.1 Road traffic network data}

150 Road network data are provided by the Norwegian Public Roads Administration (Statens Vegvesen, SVV) and are freely available through the National road database (NVDB, 2020). All roads owned and maintained by state and municipal authorities are included. Information used from these roads include geographical position, number of lanes, road category type, bridge or tunnel, signed speed, etc.. Though this database is comprehensive it is not entirely complete or correct, so some roads may not contain all the relevant data for producing traffic emissions.

\section{S4.2.2 Traffic volume data}

Most state roads in NVDB include information on traffic volume, specifically the average number of vehicle passages per day (ADT, Annual Daily Traffic). In addition, the fraction of heavy duty vehicles is also provided. Most municipal roads are not provided with ADT in the database. A traffic model, developed by the Norwegian statistical bureau SSB (Nordbeck and Langsrud, 2015) for noise modelling provides these additional municipal road data.

160

To determine hourly traffic volumes from the daily traffic data then time profiles for light and heavy duty vehicles are used. These are derived from traffic counts made by SVV at over 2000 sites throughout Norway. SVV has provided time profiles for each county in Norway as average hourly time profiles over a week, 168 hours. Currently a single average time profile is used for all of Norway, derived from these county data, for light and heavy duty traffic separately. Time profiles are very similar over most of Norway but local variations do occur.

\section{S4.2.3 Exhaust emissions}

Exhaust emissions per hour for a road are determined by multiplying the number of vehicles per hour on the road with the length of the road and with an emission factor, given as $\mathrm{g} / \mathrm{vehicle} / \mathrm{km}$. These emission factors vary significantly between vehicle types and so average emission factors are determined based on the vehicle fleet makeup. For the current implementation of the air quality forecast use is made of average emission factors derived at national level by Statistical Bureau of Norway (SSB) (SSB, 2015; 2018) and applied everywhere in Norway. Different emission factors for light and heavy duty vehicles are used. Emission factors for $\mathrm{NO}_{\mathrm{x}}$ and particle exhaust are included. These emission factors are based on the HBEFA emission model (Hausberger et al., 2009). In addition HBEFA has more recently included ambient air temperature dependence for NOx emissions (Keller et al., 2017) and other recent studies have shown a strong temperature dependence for NOx emissions 
175 (Weber et al., 2019; Hagman et al., 2011; Grange et al., 2019). A temperature dependent scaling factor is included, Eq. (S13) to take into account the hourly variation in temperature.

\section{S4.2.4 Non-exhaust emissions}

Non-exhaust emissions from road, tire and brake wear are calculated using the NORTRIP road dust emission model (Denby et al., 2013a and 2013b). This model uses information on studded tire share, traffic volume data, meteorological data and

180 winter maintenance data to calculate these emissions. The model also predicts road surface conditions and includes the buildup of road dust on the road surface during the winter months and its suspension during dry periods. NORTRIP has been developed and tested on many sites in Scandinavia (e.g. Norman et al., 2016; Stojiljkovic et al., 2019). In the current application salt, dust binding and sanding are included. These are determined based on a set of rules governing their application, dependent on meteorological conditions and on information received from a number of municipalities on their use of salt and sand. A more detailed description for the application of NORTRIP in Norway is beyond the scope of this paper but will be described in a future publication.

\section{S4.2.6 Industrial emissions}

Industrial emissions for 300 industrial sites in Norway are available from a database maintained by The Norwegian Environmental Agency (Miljødirektoratet) and the SSB (Miljødirektoratet, 2020). This database contains annual emissions for

190 a range of pollutants. The database is, however, limited as it provides no information on temporal variation of the emissions, provides just one single geographical coordinate for the emissions and provides no information on the heights or the areal distributions of the emissions. Only the largest industrial emission sources are included. Due to the limited amount of information available it is not possible to apply a plume rise model for the stack emissions so in the current forecast application all industrial emissions are set to an effective emission height of $100 \mathrm{~m}$.

\section{S4.2.7 Residential wood combustion}

Residential wood combustion is modelled using the MetVed model (Grythe et al., 2019). The model uses a combination of several data sources to determine where wood burning occurs and includes the number and type of dwellings, e.g. houses or apartments, the energy consumption of the dwellings as well as the number and type of fireplaces and stoves in use along with their associated emission factors. The different data sources are combined to provide a 'wood burning potential' for any particular group of households. This information covers all of Norway at $250 \mathrm{~m}$ resolution. In addition to the spatial distribution of the wood burning potential it is necessary to know the amount of wood consumed. This information is derived from questionnaires regularly sent out by SSB to a few thousand households who are asked, amongst other questions, about their wood burning habits. From this the total wood consumption per year and per county in Norway is estimated and the wood consumption is distributed using the 'wood burning potential' determined with the MetVed model. 
Wood burning varies with time. Most wood burning occurs in the evenings and in the weekends when people are at home. In addition wood burning is dependent on the outside temperature and to a lesser extent precipitation and humidity. In the MetVed model a daily and weekly burning cycle is used, based on questionnaire data about when people use their wood stoves (Aasestad, 2010). This cycle covers each hour of the week and is the same for all of Norway. The influence of temperature is

210 included in the model using the heating degree day concept. Total emissions are distributed over the year based on the heating degree day value for each day for temperatures less than $+11^{\circ} \mathrm{C}$. A single emission height of $15 \mathrm{~m}$ is used which reflects wood burning emissions from free standing houses.

\section{S4.2.8 Shipping emissions}

Shipping emissions are calculated with the help of AIS (Automatic Identification System) data. All ships of any reasonable

215 size have an AIS transmitter installed. This sends the position and identity of the ship to both satellite and mast receivers every few minutes. With this the ships position is continuously tracked. Emissions are calculated using a model, hosted by the Norwegian Coastal authorities (Havbase, 2020). This model takes into account the ship type, size, weight and engine type and uses the change of position of the ship to calculate speed and engine load. When the ship is not moving it is assumed to be at port. While the AIS transmitter is on, then the ship engines are assumed to be running and the ship will be emitting exhaust pollutants. The Norwegian coastal authorities (Kystverket) provide this information along with a public website for viewing ship movements using the AIS data.

Shipping emission point data are aggregated into $250 \times 250 \mathrm{~m}^{2}$ grids along the coast of Norway. Monthly means are made for each month of the year (2017) and these monthly means are used for the same month every year. In addition an average daily time profile (24 hours) is made for every month at $2.5 \mathrm{~km}$ resolution to take into account regular variations in shipping emissions. As in industry large ships emit exhaust from high stacks. The emitted exhaust is most often warmer than the surrounding air and will rise. Information necessary to calculate the emission height is not easily available. Since the largest emitters have high stacks and warm emissions then ship emissions are currently set to a height of $70 \mathrm{~m}$.

\section{S5. Model verification and sensitivity tests}

\section{S5.1 Comparison of annual and hourly mean calculations}

In Sect. 3 we describe two methods for calculating dispersion. One is based on the hourly meteorological and emission data, Sect. 3.1, and the other on annual mean data, Sect. 3.2. The hourly and annual calculations will differ in several ways:

1. The dispersion function used in the two applications usually differs, the hourly calculation is based on the use of $\mathrm{K}_{z}$ and the annual on simpler distance functions to describe plume dispersion 
2. The annual calculations assume homogeneity in wind direction and no correlation between wind speed, stability and boundary layer height.

3. Emissions from some pollutant sources, for example road dust and residential wood burning, vary significantly during the year. The annual concentrations do not take into account any temporal correlation between wind speed, direction, stability or boundary layer height and the emissions

We compare the annual and hourly calculations for the same $100 \times 100 \mathrm{~km}^{2}$ region surrounding Oslo with a resolution of 100 m, Fig. S1. For the annual calculations the means of all emissions and all meteorological parameters are applied. For wind speed the mean of the inverse of the wind speed is used. To assess the differences that occur due to points 2 and 3 above we have made hourly calculations using the same dispersion parameters applied in the annual calculation, using the simple parameterisation given in Eq. (24). The dispersion factors from ASME (Smith, 1973) are used in the calculations.

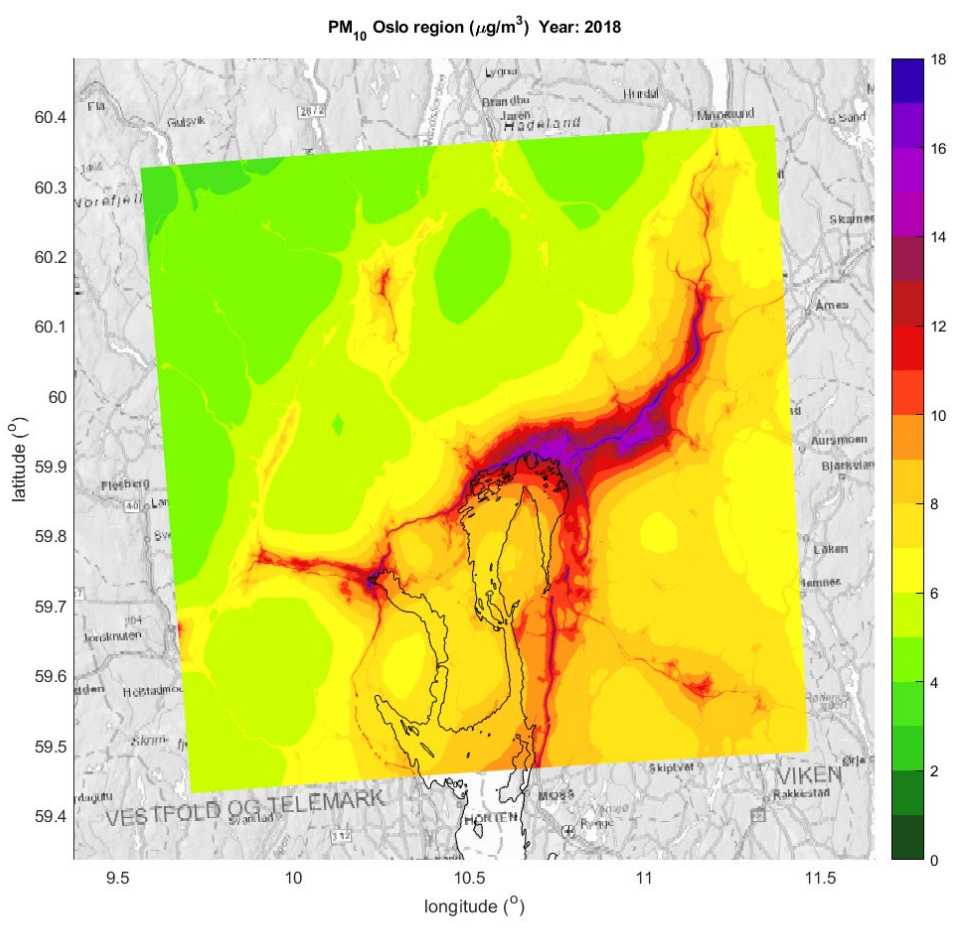

Figure S1. $100 \mathrm{~km}$ modelling domain used for the intercomparison of hourly and annual concentrations centred on Oslo at $100 \mathrm{~m}$ resolution. Shown is the annual mean concentration of $\mathbf{P M} 10$ for the year 2018 as calculated using the hourly calculation method (Ckartverket/norgeskart.no).

For the conserved pollutants of $\mathrm{PM}_{10}$ and $\mathrm{PM}_{2.5}$ the scatter plots show very similar results for the two model calculations when applying the simple dispersion parameters to both hourly and annual calculations. There is not a one to one correspondence 
for the $\mathrm{NO}_{2}$ comparison. This is because the two chemical parameterisations, discrete parcel method and empirical fit, are not equivalent.

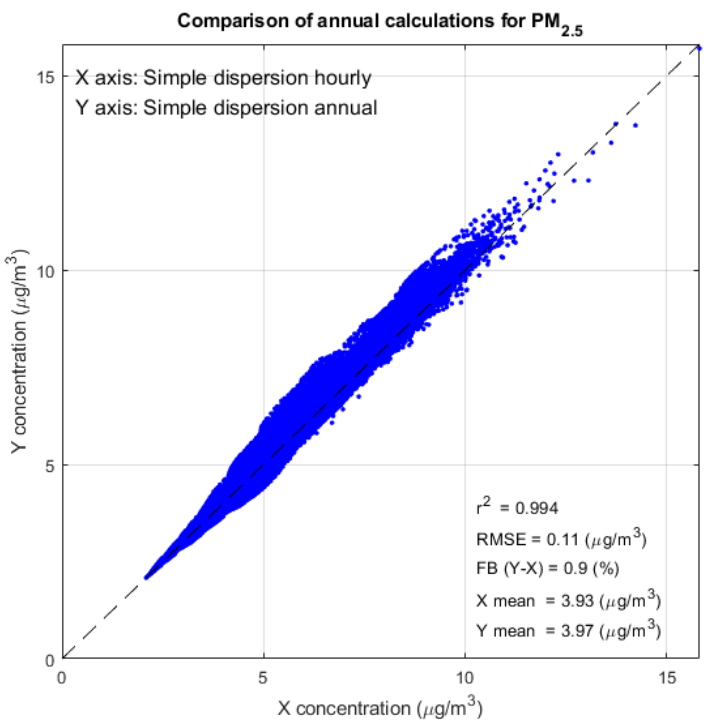

(a)

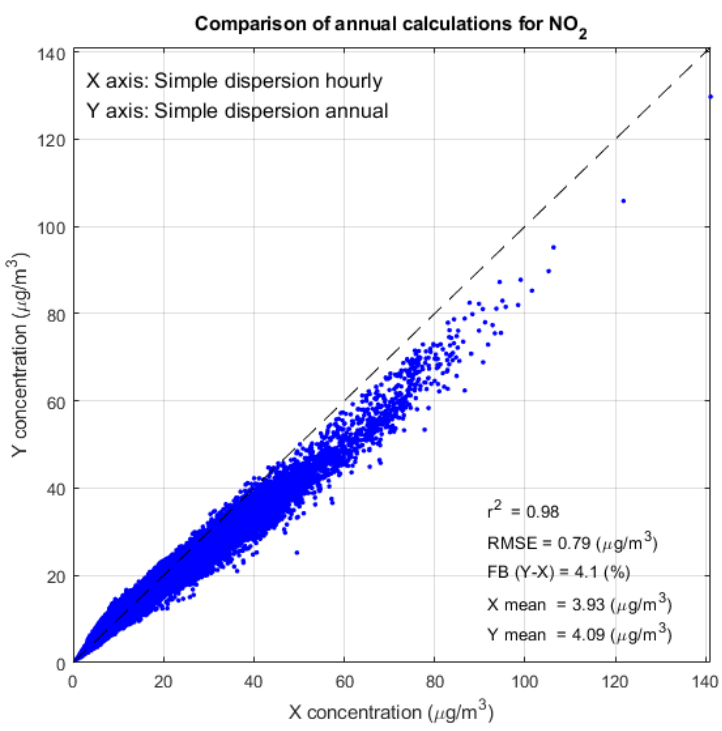

(c)

Figure S2. Comparison of the single annual mean calculation with the annual mean of hourly calculations in the Oslo region, 2018, for $\mathrm{PM}_{2.5}$ (a), $\mathrm{PM}_{10}$ (b) and $\mathrm{NO}_{2}$ (c). A simple version of the dispersion scheme has been used so that both hourly and annual

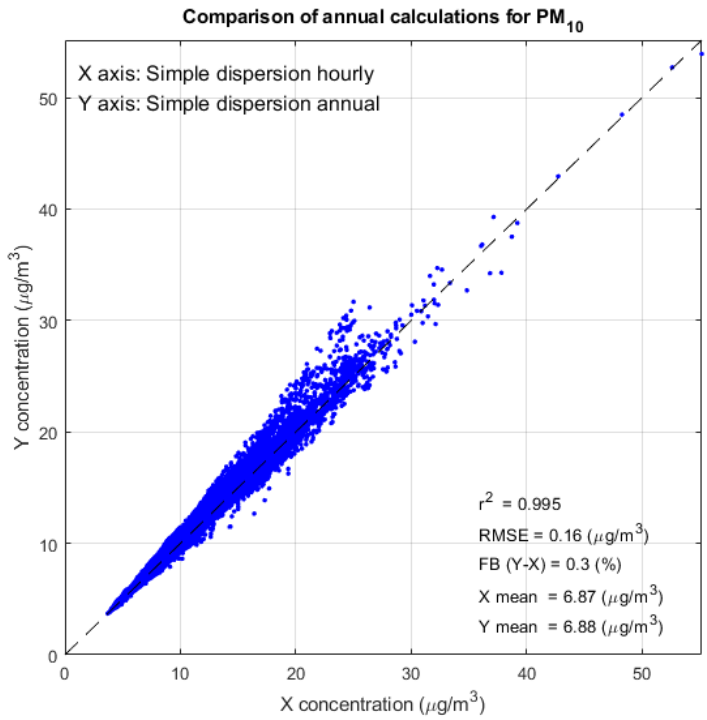

(b) 
In Fig. S3 we compare the same single annual calculation with the hourly calculation but this time using the $\mathrm{K}_{\mathrm{z}}$ parameterisation for determining the dispersion. In this case the results are not the same, though similar. This indicates that the $\mathrm{K}_{z}$ parameterisation provides, not surprisingly, different results to the simple dispersion parameter calculation.

It is worth noting that the emission sources near the surface are best represented by the single annual calculation. Elevated releases, such as shipping, industry and residential wood burning do not correspond as well to the hourly calculations. We conclude that good estimates of the concentration fields for $\mathrm{PM}$ and $\mathrm{NO}_{2}$ can be obtained using just the simple annual calculation and that $\mathrm{NO}_{2}$ will require an improvement in the chemistry parameterisation. The dispersion parameters used in 270 the annual calculation are the same under all conditions and their description should be improved to be more compatible with the $K z$ dispersion parameterisation. This is an important point because the run time for the single annual calculation is a factor of 10000 faster than modelling each individual hour. If similar results are obtainable with a single calculation then this aspect of the model should be developed further.

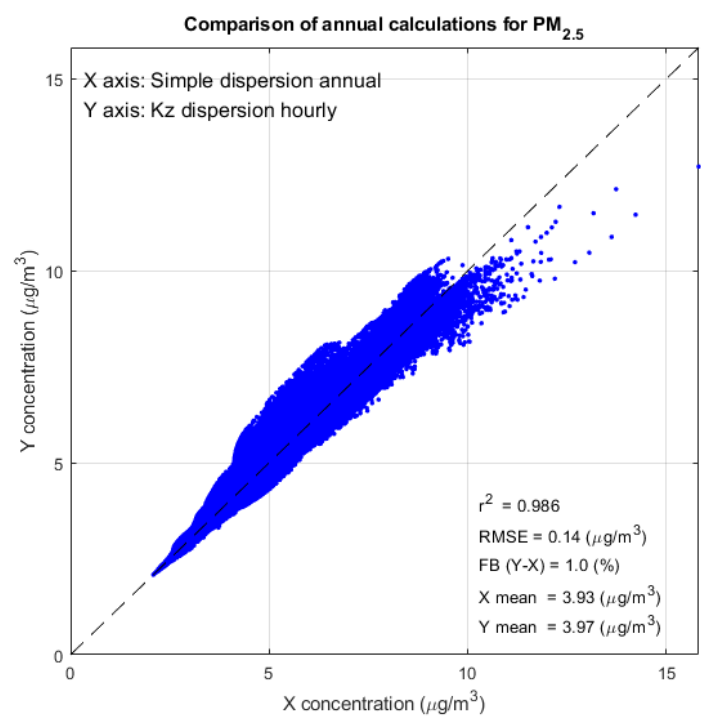

(a)

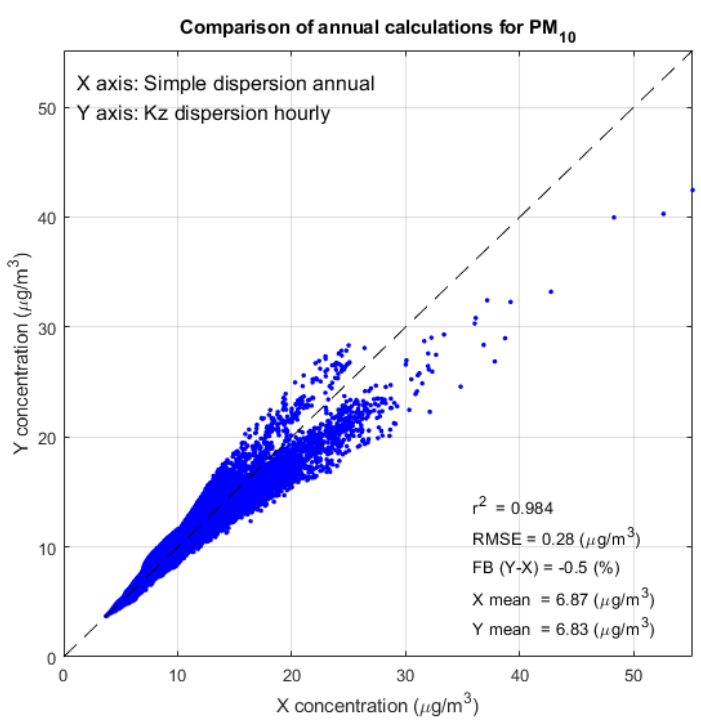

(b) 


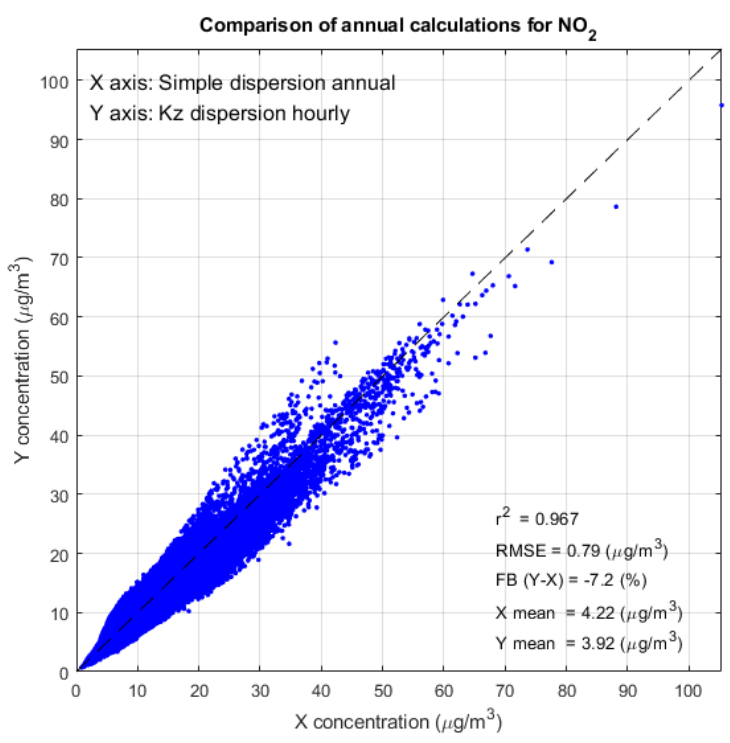

(c)

Figure S3. Comparison of the single annual mean calculation with the annual mean of hourly calculations in the Oslo region, 2018, for $\mathrm{PM}_{2.5}$ (a), $\mathrm{PM}_{10}$ (b) and $\mathrm{NO}_{2}$ (c). A simple version of the dispersion scheme has been used for the single annual calculation but the $\mathrm{Kz}$ based dispersion parameterisation has been used for the hourly calculations.

\section{S5.2 Sensitivity to moving window size}

For the Norwegian forecasting system a local fraction region of 5 EMEP grids is applied, Sect. 2.3. The uEMEP calculation region is set to 4 EMEP grid sizes so the moving window is always covered by the local fraction region, Sect. 2.4. It is interesting to see what impact a change in the size of this region will have on the calculated concentrations. To assess this we conducted an experiment where the local fraction region was extended to 9 EMEP grids and calculated the concentrations at all Norwegian measurement sites using different uEMEP moving window calculation regions, ranging from 8 (20 km) to 1 $(2.5 \mathrm{~km})$ EMEP grids. The assessment was carried out for the month of March 2017 when high emissions of road dust provided strong local contributions to $\mathrm{PM}_{10}$.

290 The results for both $\mathrm{PM}_{10}$ and $\mathrm{NO}_{2}$ are shown in Fig. S4 and S5. The behaviour of the model is as expected. As the uEMEP calculation region goes from large to small then less local contributions and more non-local EMEP contributions will occur. Non-local contributions from EMEP in $\mathrm{PM}_{10}$ that are not primary remain constant whilst the primary emission contribution from EMEP increases. It could be expected that the smaller the local region is then the lower the concentrations, but the results show that for $\mathrm{PM}_{10}$ there is little difference between any of the region sizes. This shows the uEMEP integration method is working well and the resulting concentrations are not sensitive to the choice of region. 
For $\mathrm{NO}_{2}$ there is a steady decrease in concentration from larger to smaller regions, though this only starts to be significant for 2 grids (when compared to the 8 grid case). The choice of a uEMEP calculation region of 4 EMEP grids reflects these results. There is only a $2.5 \%$ difference when doubling the region to 8 grids, whilst in so doing the calculation time increases roughly 300 four fold. The difference in local contribution between the 4 and 8 grid region is around $1.5 \mu \mathrm{g} / \mathrm{m}^{3}$ for $\mathrm{NO}_{2}$, or $7 \%$. This tells us that $7 \%$ of the concentration, on average for all stations, comes from the region between 5 and $10 \mathrm{~km}$ away. For $\mathrm{PM}_{10}$ this is around $4 \%$.

(a)
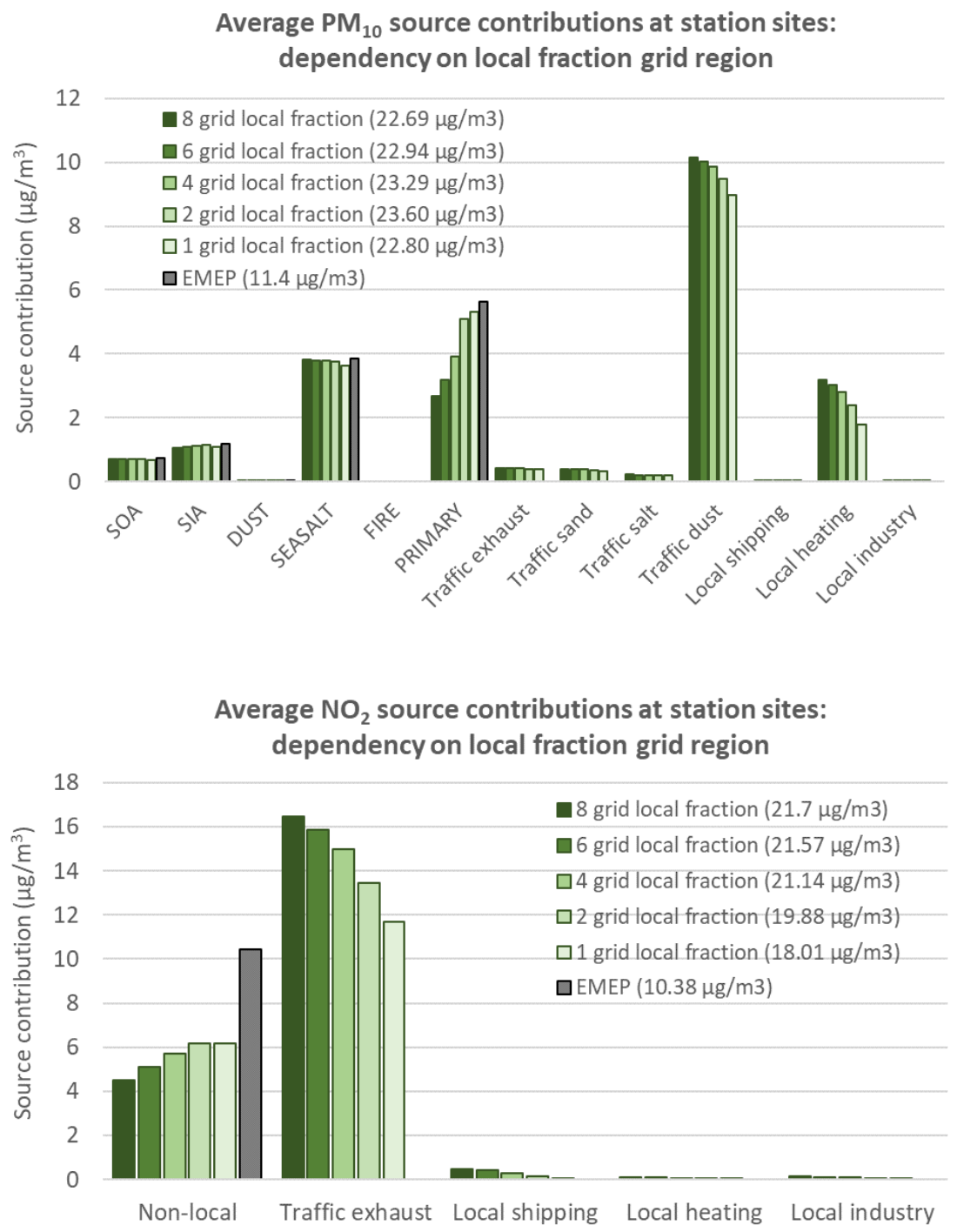
Figure S4. Change in the average concentrations at all measurement sites in Norway (72) per contributing sector with a change in the local fraction (moving window) grid region from 1 to 8 EMEP grids. EMEP contributions are given in capitals and uEMEP contributions are given in normal text. SOA, SIA, DUST, SEASALT and FIRE (forest) are the PM10 source contributions from EMEP not modelled with UEMEP. Only the PRIMARY source contributions from EMEP are included in the local fraction calculation. All uEMEP source contributions (Traffic exhaust, Traffic sand, Traffic salt, Traffic dust (road), Local shipping, Local heating and Local industry) are shown. (a) is for $\mathrm{PM}_{10}$ and (b) for $\mathrm{NO}_{2}$.

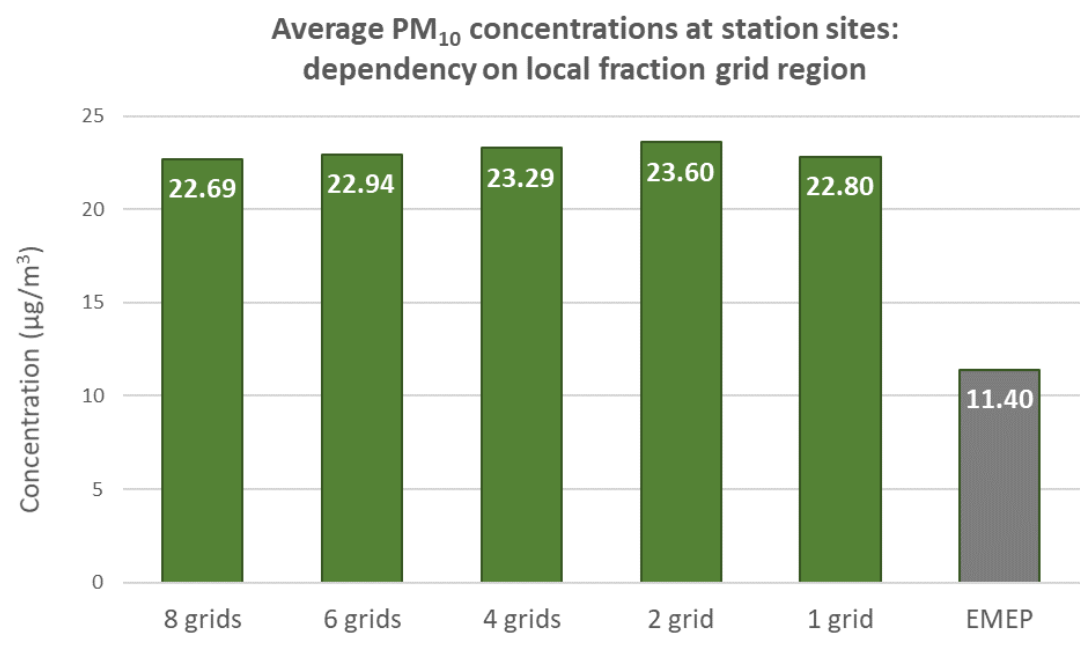

(a)

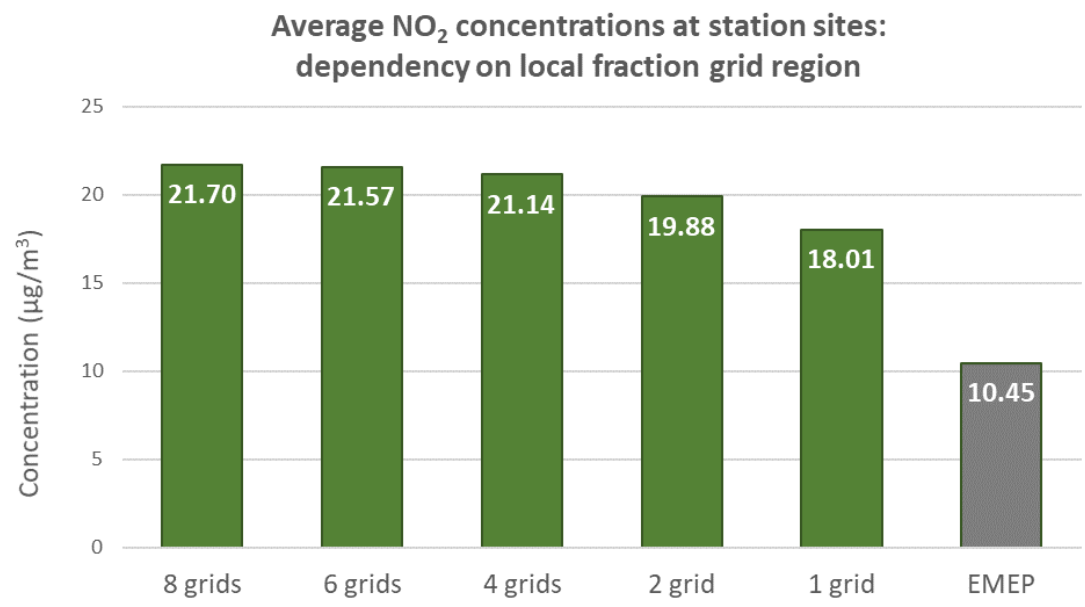

(b)

Figure S5. As in Fig. S2 but only showing the total average concentration at all measurement sites in Norway with a change in the local fraction (moving window) grid region from 1 to 8 EMEP grids. (a) is for $\mathrm{PM}_{10}$ and (b) for $\mathrm{NO}_{2}$. 


\section{S5.3 Sensitivity to sub-grid resolution}

The size of the receptor sub-grids is an important parameter in the model. Even though these are termed 'grids' they are in fact Gaussian point calculations, centred in each sub-grid. The sub-grid resolution determines the dilution of emissions as well as

320 the extent of their distribution. The resolution is also important for the calculation time, since it scales with the number of calculations by the power of 4 (halving of the sub-grid resolution results in a 16 fold increase in the number of calculations) and so has practical implications for implementation. Concentration calculations several sub-grids away from sources should be insensitive to the choice of sub-grid resolution but for calculations close to sub-grid emissions this can be important, in particular when comparing model results to observed concentrations at measurement sites. In the forecast application sub-grids

325 in densely populated areas have a resolution of $50 \mathrm{~m}$, but in most areas this is reduced to $100 \mathrm{~m}$. For measurement site calculations a resolution of $25 \mathrm{~m}$ is applied.

In Fig. S6 and S7 we show the results of a sensitivity analysis on sub-grid resolution for $\mathrm{NO}_{2}$. Calculations are made at measurement sites for a range of sub-grid resolutions from $15 \mathrm{~m}$ to $250 \mathrm{~m}$ for the year 2017 . Also included are the results of a 330 shift of the $25 \mathrm{~m}$ sub-grid by half a grid ('Shift $1 / 2$ grid $25 \mathrm{~m}$ ') along with the $2.5 \mathrm{~km}$ EMEP model calculation, without the use of uEMEP ('EMEP’).

We see that there is little difference in the annual mean concentrations at individual stations for resolutions between 15 and $100 \mathrm{~m}$, Fig. S6. The relative RMSE when compared to the $25 \mathrm{~m}$ calculation is less than $6 \%$ for up to $100 \mathrm{~m}$, Fig. S7. Larger differences occur, both positive and negative, for the $250 \mathrm{~m}$ grid which show RMSE deviations from the $25 \mathrm{~m}$ calculation of $11 \%$. On average over all stations, Fig. S7, we see that there are only small changes due to a change in resolution.

Most monitoring stations in the Norwegian air quality network are traffic stations, positioned close to roads. This means that many of the sites are within the emitting sub-grid and the resulting concentrations will depend on the initial dispersion. In Fig.

340 S7 we see that the effect of decreasing resolution can lead to both positive and negative deviations. The first occurs when a station is positioned in the low resolution emitting sub-grid, but not in the high resolution emitting sub-grid, and the second occurs when a station is in the high resolution emitting sub-grid and dilution of the emissions with low resolution sub-grids leads to a decrease in concentrations. On average these effects cancel, leading to relative little change in the average concentrations over all stations. 

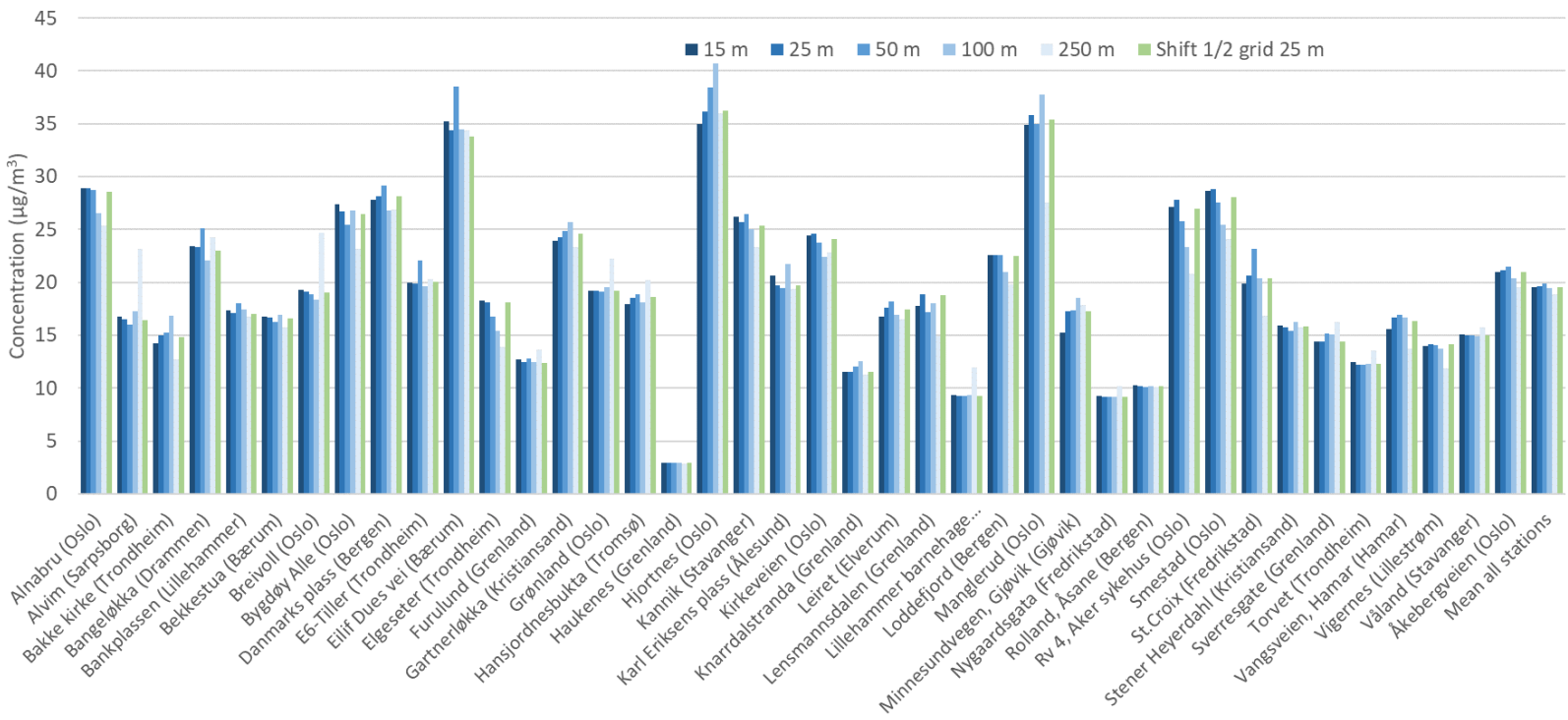

(a)

Sensitivity of annual mean $\mathrm{NO}_{2}$ concentrations to sub-grid resolution at air quality station sites
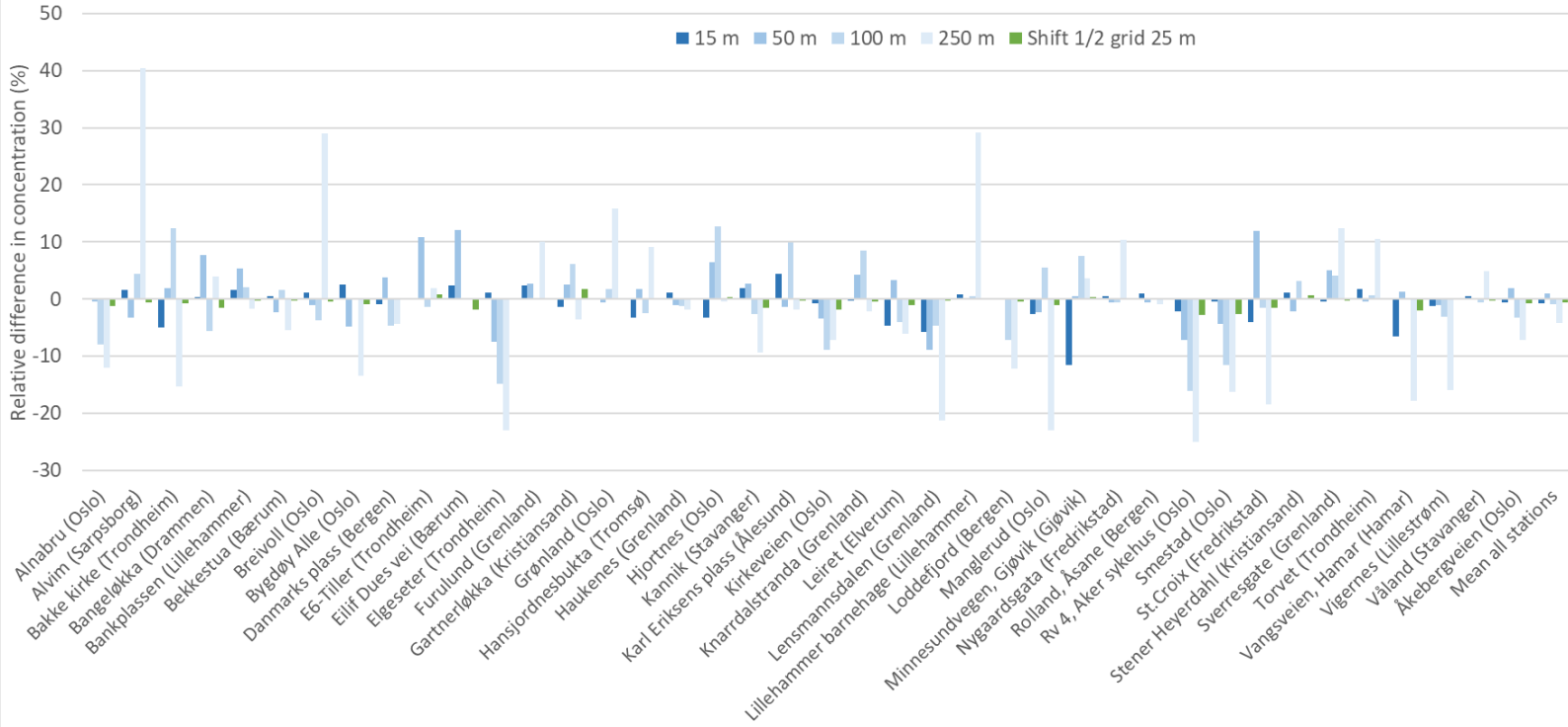

(b)

Figure S6. (a) The calculated annual mean $\mathrm{NO}_{2}$ concentrations for a range of sub-grid resolutions, $15-250 \mathrm{~m}$. (b) The relative change, compared to the 25 calculation, in annual mean $\mathrm{NO}_{2}$ concentrations. Calculation year is 2017. 
Average $\mathrm{NO}_{2}$ concentrations at measurement stations for varying sub-grid resolutions

25

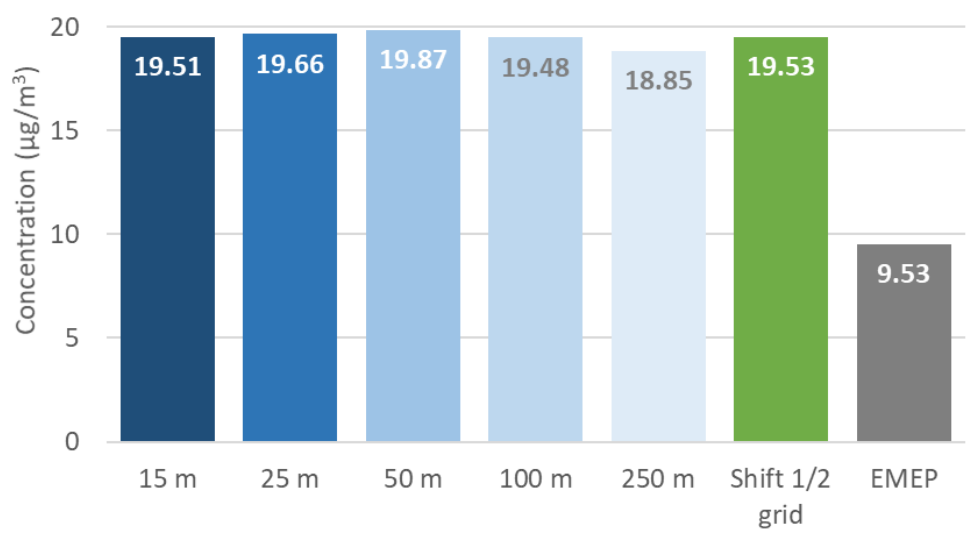

(a)

Normalised RMSE of $\mathrm{NO}_{2}$ concentrations relative to $25 \mathrm{~m}$ resolution at measurement stations for varying sub-grid

12 resolutions

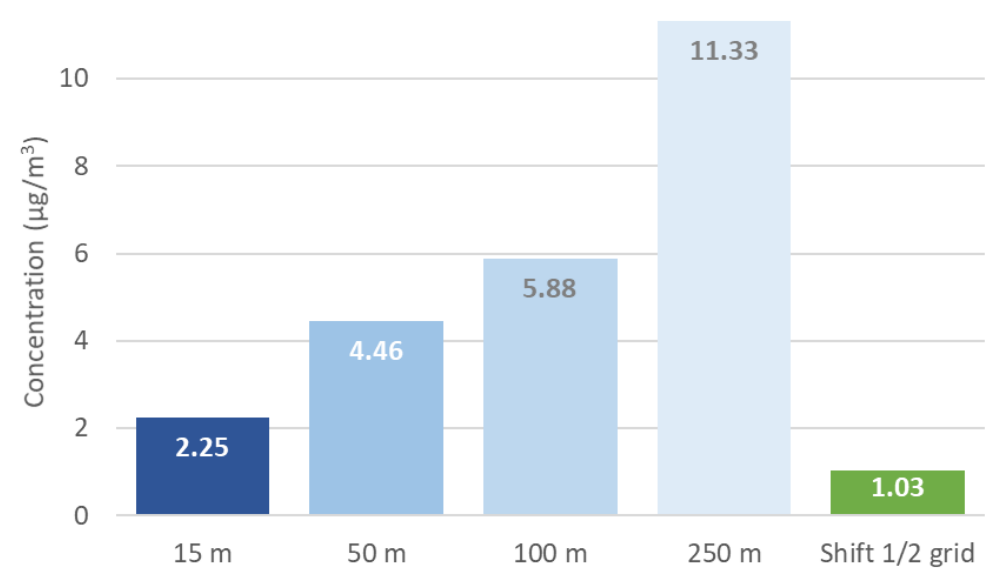

(b)

Figure S7. (a) The calculated annual mean $\mathrm{NO}_{2}$ concentrations for all stations over a range of sub-grid resolutions, 15 - $250 \mathrm{~m}$. (b) The relative normalised RMSE, compared to the $25 \mathrm{~m}$ calculation, in annual mean $\mathrm{NO}_{2}$ concentrations. Calculation year is 2017. 


\section{S5.4 Temperature dependence of $\mathrm{NO}_{\mathrm{x}}$ traffic emissions}

In Sect. S3.4.4 the implementation of a traffic exhaust $\mathrm{NO}_{\mathrm{X}}$ emission temperature dependence is described. To test the sensitivity of the model calculations to this assumption then the parameterisation is turned off and the calculations for 2017 redone. The results show a significant reduction in the station mean time series correlation (Fig. S8), from $\mathrm{r}^{2}=0.79$ to 0.68 ,

360 without the temperature dependence. The annual mean correlation is also slightly reduced (Fig. S9), from $\mathrm{r}^{2}=0.78$ to 0.76 . Average negative bias also increases from $-3 \%$ to $-20 \%$. These results indicate the need for the temperature dependent traffic exhaust $\mathrm{NO}_{\mathrm{x}}$ emissions.

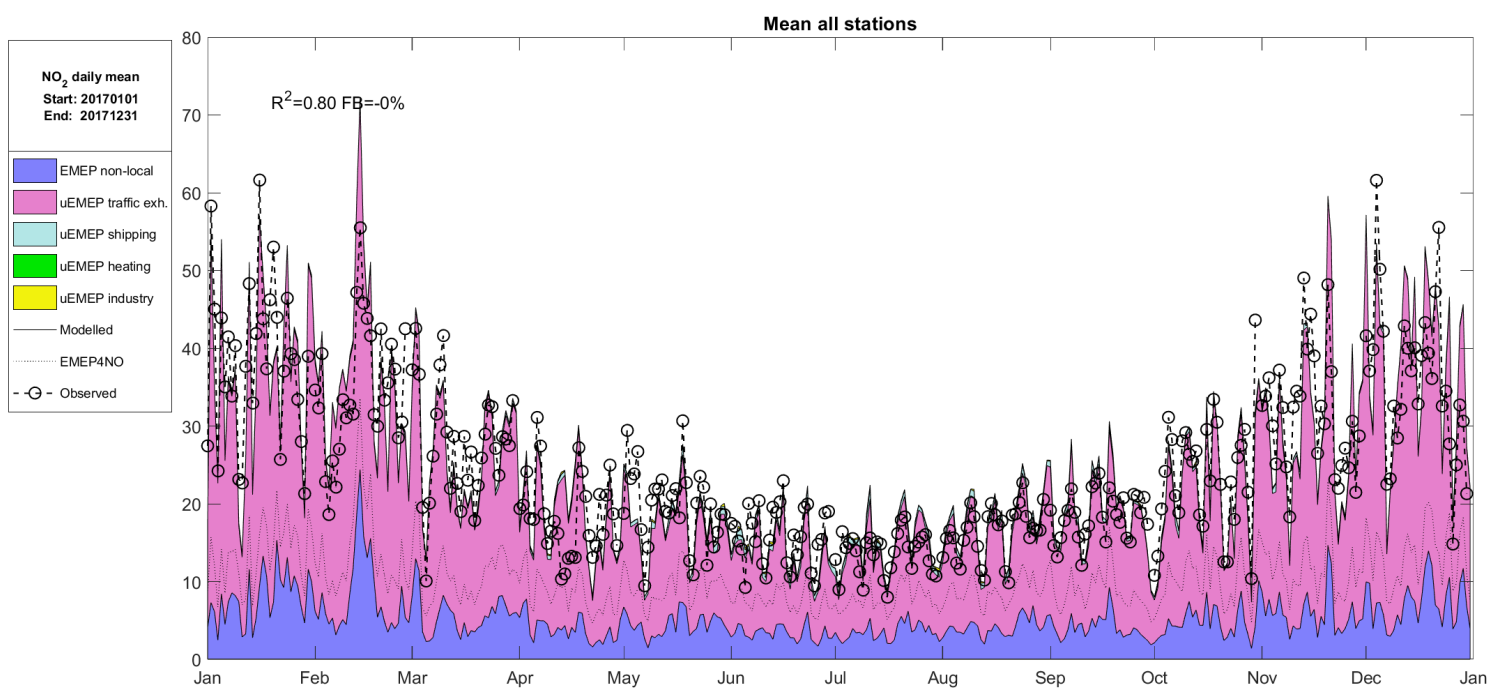

(a)

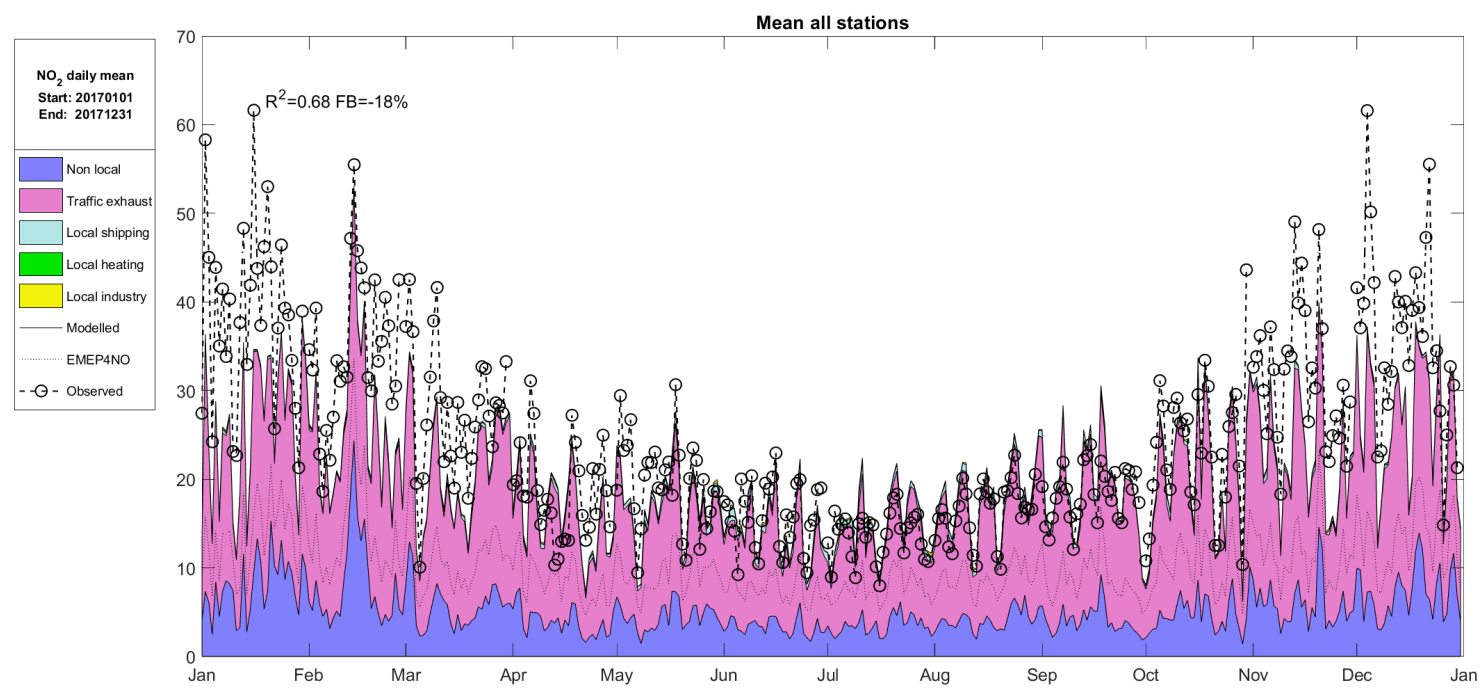


Figure S8. Daily mean time series, average all stations, for $\mathrm{NO}_{2} 2017$. (a) is the standard calculation with temperature correction and (b) without temperature correction. EMEP calculations are not affected by the temperature correction in this sensitivity assessment.

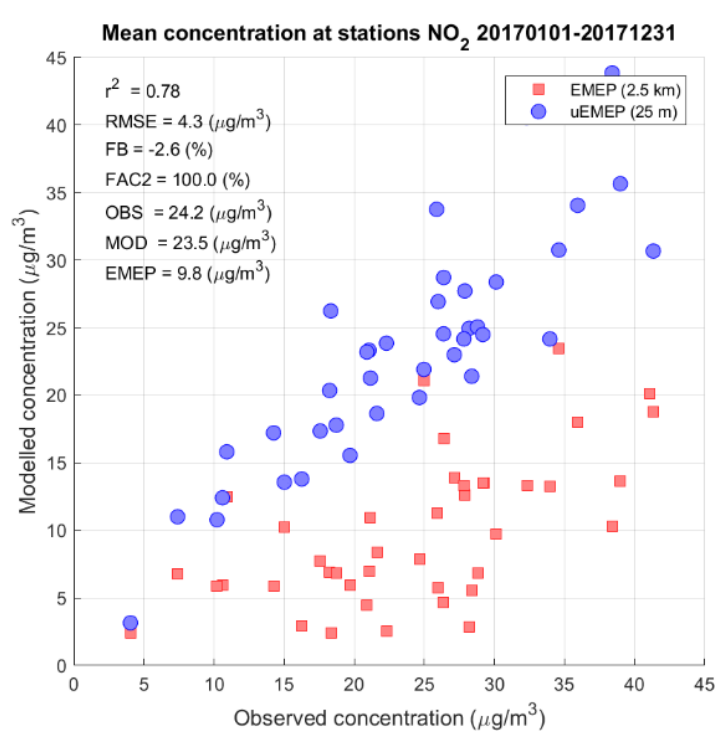

(a)

(b)

Figure S9. Annual mean scatter plots for all stations for $\mathrm{NO}_{2} 2017$. (a) is the standard calculation with temperature correction and (b) without temperature correction. EMEP calculations are not affected by the temperature correction in this sensitivity assessment.

\section{$\mathrm{S5.5} \mathrm{NO}_{2} / \mathrm{NO}_{\mathrm{x}}$ emission ratio}

In Sect. 3.4 the $\mathrm{NO}_{2}$ chemistry scheme is described. One parameter in this is the initial $\mathrm{NO}_{2} / \mathrm{NO}_{\mathrm{x}}$ emission ratio $\left(f_{\mathrm{NO} 2,0}\right)$. For all emissions except traffic exhaust this is set to 0.1 in the model calculations. However, for traffic exhaust this is set to a higher value of 0.25 , which reflects the high percentage of diesel vehicles in the Norwegian traffic fleet, as these can have $\mathrm{NO}_{2} / \mathrm{NO}_{\mathrm{x}}$ emission ratios of up to 0.45 (Hagman et al., 2011). A sensitivity test was carried out for this ratio using three alternative values for the initial traffic exhaust $\mathrm{NO}_{2} / \mathrm{NO}_{\mathrm{x}}$ ratio of $0.15,0.25$ (current) and 0.35 . These calculations were carried out at monitoring sites for the year 2017. In Fig. S10 the modelled $\mathrm{NO}_{2}$ is plotted against $\mathrm{NO}_{\mathrm{x}}$ using the three alternative values. Also included in the plot is the empirical fit to annual mean observations, Sect. 3.5. The ratio used in the model will affect the final $\mathrm{NO}_{2} / \mathrm{NO}_{\mathrm{x}}$ ratio, particularly for the highest $\mathrm{NO}_{\mathrm{x}}$ concentrations that represent traffic stations on

385 busy roads. A value of 0.15 places the modelled $\mathrm{NO}_{2} / \mathrm{NO}_{\mathrm{x}}$ concentrations much closer to the empirical fit to observations and will be used in future calculations. 


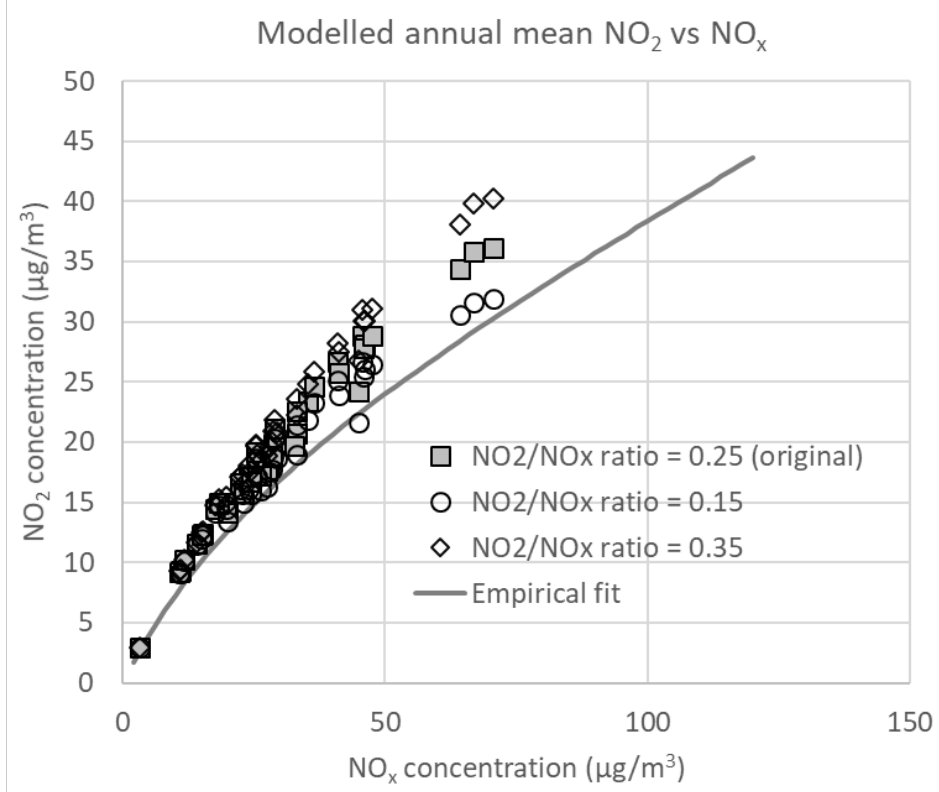

Figure S10. Impact of a change in the initial $\mathrm{NO}_{2} / \mathrm{NO}_{\mathrm{X}}$ emission ratios for traffic for three cases where $\boldsymbol{f}_{N O 2,0}=0.15,0.25$ and 0.35 . Also shown is the empirical fit to observations given in Sect. 3.5.

\section{Supplementary material references}

Aasestad, K.: Vedforbruk, fyringsvaner og svevestøv, dokumentasjon og resultater fra undersøkelse i Drammen 2006/2007 (Fire wood consumption, heating habits and particulate matter, documentation and results from questionaires in Drammen 20062007), Statistics Norway, Oslo, In Norwegian, ISBN 978-82-537-7823-5, 2010. URL: https://www.ssb.no/natur-og-

395 miljo/artikler-og-publikasjoner/vedforbruk-fyringsvaner-og-svevestov--26206

Denby, B.R., Sundvor, I., Johansson, C., Pirjola, L., Ketzel, M., Norman, M., Kupiainen, K., Gustafsson, M., Blomqvist, G. and Omstedt, G.: A coupled road dust and surface moisture model to predict non-exhaust road traffic induced particle emissions (NORTRIP). Part 1: road dust loading and suspension modelling, Atmos. Environ., 77, 283-300, 400 doi:10.1016/j.atmosenv.2013.04.069, 2013a.

Denby, B.R., Sundvor, I., Johansson, C., Pirjola, L., Ketzel, M., Norman, M., Kupiainen, K. , Gustafsson, M., Blomqvist, G., Kauhaniemi, M. and Omstedt, G.: A coupled road dust and surface moisture model to predict non-exhaust road traffic induced particle emissions (NORTRIP). Part 2: surface moisture and salt impact modelling. Atmos. Environ., 81, 485-503, doi: 405 10.1016/j.atmosenv.2013.09.003, 2013b. 
Etling, D.: On plume meandering under stable stratification, Atmospheric Environment. Part A. General Topics, 24(8), 19791985, doi:10.1016/0960-1686(90)90232-C, 1990.

410 Garratt, J.R.: The Atmospheric Boundary Layer, Cambridge Univ. Press, Cambridge, U.K., 316 pp, 1994.

Grange, S.K., Farren, N.J., Vaughan, A.R., Rose, R.A. and Carslaw, D.C.: Strong Temperature Dependence for Light-Duty Diesel Vehicle NOx Emissions. Environmental Science \& Technology 53(11), 6587-6596, doi:10.1021/acs.est.9b01024, 2019.

415 Granier, C., S. Darras, H. Denier van der Gon, J. Doubalova, N. Elguindi, B. Galle, M. Gauss, M. Guevara, J.-P. Jalkanen, J. Kuenen, C. Liousse, B. Quack, D. Simpson and K. Sindelarova: The Copernicus Atmosphere Monitoring Service global and regional emissions (April 2019 version), Report April 2019 version, null, doi:10.24380/d0bn-kx16, 2019

Gryning, S., Batchvarova, E. and Brümmer, B.: On the extension of the wind profile over homogeneous terrain beyond the surface boundary layer, Boundary-Layer Meteorol., 124, 251-268, doi:10.1007/s10546-007-9166-9,_2007.

Grythe, H., Lopez-Aparicio, S., Vogt, M., Vo Thanh, D., Hak, C., Halse, A. K., Hamer, P., and Sousa Santos, G.: The MetVed model: Development and evaluation of emissions from residential wood combustion at high spatio-temporal resolution in Norway, Atmos. Chem. Phys. Discuss., doi:10.5194/acp-2019-95, 2019. URL: https://www.atmos-chem-phys425 discuss.net/acp-2019-95/

Hagman, R., Gjerstad, K.I. \& Amundsen, A.H., 2011. NO2-utslipp fra kjøretøyparken i norske storbyer, TØI rapport 1168/2011: Transportøkonomisk institutt, Oslo. https://www.toi.no/getfile.php? $\mathrm{mmfileid=22618}$

430 Hausberger, S., Rexeis, M., Zallinger, M. and Luz, R. (2009): Emission factors from the model PHEM of the HBEFA Version 3.1, Report Nr. I-20/2009 Haus-Em 33/08/679, Graz: www.hbefa.net

Havbase, 2020. URL: https://havbase.no/

435 Hiscox, A. L., Miller, D. R., and Nappo, C. J. ( 2010), Plume meander and dispersion in a stable boundary layer, J. Geophys. Res., 115, D21105, doi:10.1029/2010JD014102.

Jeričevič, A., Kraljevic, L., Grisogono, B., Fagerli, H., and Vecenaj, Z.: Parameterization of vertical diffusion and the atmospheric boundary layer height determination in the EMEP model, Atmos. Chem. Phys., 10, 341-364, doi:10.5194/acp$440 \quad 10-341-2010,2010$ 
Keller M., Hausberger S., Matzer C., Wüthrich P., Notter B.: HBEFA Version 3.3, Background documentation, Berne, 2017. URL: https://www.hbefa.net/e/documents/HBEFA33_Documentation_20170425.pdf

445 Kuenen, J. J. P., Visschedijk, A. J. H., Jozwicka, M., and Denier van der Gon, H. A. C.: TNO-MACC_II emission inventory; a multi-year (2003-2009) consistent high-resolution European emission inventory for air quality modelling, Atmos. Chem. Phys., 14, 10963-10976, 2014 doi:10.5194/acp-14-10963-2014

Miljødirektoratet: Industry emissions, 2020. URL: https://www.norskeutslipp.no/en/Industrial-activities/?SectorID=600 450

Nordbeck, O. and Langsrud, Ø.: Modellering av trafikk på kommunale veier, beskrivelse av metode (Modelling of traffic on municiple roads a description of the method), in Norwegian, SSB Report (Notater) 2015/46, 2015. URL: https://www.ssb.no/transport-og-reiseliv/artikler-og-publikasjoner/modellering-av-trafikk-pa-kommunale-veier

455 Norman, M., Sundvor, I., Denby, B.R., Johansson, C., Gustafsson, M., Blomqvist, G., Janhäll, S.: Modelling road dust emission abatement measures using the NORTRIP model: Vehicle speed and studded tyre reduction, Atmos. Environ., 134, 96-108, doi:10.1016/j.atmosenv.2016.03.035, June 2016.

NVDB: Nasjonal vegddatabank, Statens vegvesen, (Norwegian national road database), 2020. URL: 460 https://www.vegvesen.no/fag/teknologi/nasjonal+vegdatabank

O'Brien, J. J.: A Note on the vertical structure of the eddy exchange coefficient in the planetary boundary layer, J. Atmos. Sci., 27, 1213-1215, 1970.

465 Pielke, R.: Mesoscale meteorological modelling. Second Edition, Academic Press, 2002.

Simpson, D., Benedictow, A., Berge, H., Bergström, R., Emberson, L. D., Fagerli, H., Flechard, C. R., Hayman, G. D., Gauss, M., Jonson, J. E., Jenkin, M. E., Nyíri, A., Richter, C., Semeena, V. S., Tsyro, S., Tuovinen, J.-P., Valdebenito, Á., and Wind, P.: The EMEP MSC-W chemical transport model - technical description, Atmos. Chem. Phys., 12, 7825-7865, 470 doi:10.5194/acp-12-7825-2012, 2012.

Smith M.E. (ed) (1973). Recommended Guide for the Prediction of the Dispersion of Airborne Effluents. Vol. 2 Amer. Soc.Mech. Eng., New York, 85 pp. 
475 SSB: Emissions of acidifying gases and ozone precursors, 2018. URL: https://www.ssb.no/natur-og-miljo/statistikker/agassn

SSB: Utslipp fra veitrafikken i Norge. Dokumentasjon av beregningsmetoder, data og resultater (Emission from road traffic in Norway. Documentation of the calculation method, data and results), in Norwegian, SSB Report (Notater) 2015/22, 2015. URL: https://www.ssb.no/natur-og-miljo/artikler-og-publikasjoner/utslipp-fra-veitrafikken-i-norge

480

Stojiljkovic, A., Kauhaniemi, M., Kukkonen, J., Kupiainen, K., Karppinen, A., Denby, B.R., Kousa, A., Niemi, J.V. and Ketzel, M.: The impact of measures to reduce ambient air PM10 concentrations originating from road dust, evaluated for a street canyon in Helsinki, Atmos. Chem. Phys., 19, 11199-11212, doi:10.5194/acp-19-11199-2019, 2019

485 Weber, C., Sundvor, I., Figenbaum, E.: Comparison of regulated emission factors of Euro 6 LDV in Nordic temperatures and cold start conditions: Diesel- and gasoline direct-injection, Atmos. Environ., 206, 208-217, doi:10.1016/j.atmosenv.2019.02.031, 2019. 